\title{
Textbook Evaluation: The Communicative Imperativeness of Illustrative Materials for Effective Teaching Outcomes in Nigeria
}

\author{
Lambert A. Ihebuzor ${ }^{1}$, Noel A. Ihebuzor ${ }^{2}$ \\ ${ }^{1}$ Department of Mass Communication and Media Technology, Lead City University, Ibadan, Nigeria \\ ${ }^{2}$ Independent Consultant, City View Estate, Abuja, Nigeria \\ Email: lambert.ihebuzor@yahoo.com, noel.ihebuzor@gmail.com
}

Received 3 July 2015; accepted 21 July 2015; published 28 July 2015

Copyright (C) 2015 by authors and OALib.

This work is licensed under the Creative Commons Attribution International License (CC BY). http://creativecommons.org/licenses/by/4.0/

(c) (i) Open Access

\begin{abstract}
This paper examines the importance of effective graphics of communication in the design of books for effective teaching-learning outcomes. The paper underscores the critical importance of textbooks in the teaching-learning dyadic relationship. It reiterates the fact that textbooks are veritable sources of information and communication to the teachers and learners. It thus elucidates the need for the provision of suitable illustrative materials for textbook publishing and development. The paper then goes on to examine the critical issues when assessing and evaluating the quality of illustrations in books.
\end{abstract}

Keywords

Graphics of Communication, Illustrative Materials, Textbook Evaluation

Subject Areas: Education

\section{Introduction}

The world is currently going through a period of rapid social and technological change, the most outstanding being the globalisation and the rapid IT revolution. These two revolutions are indeed mutually reinforcing with globalisation creating demands for new technologies which accelerate the pace of globalisation. The new technologies on their part have also brought about far-reaching changes in many spheres of human life from banking, commerce, social networking, dating and even governance. Another area where these new technologies have brought about major changes is in the quantum of information that is available to us and the way such information is packaged and how we access them. The world is now saturated with visual and audio images and signals respectively, and children are now "locked" into TV screens and captives of highly interactive but addictive

How to cite this paper: Ihebuzor, L.A. and Ihebuzor, N.A. (2015) Textbook Evaluation: The Communicative Imperativeness of Illustrative Materials for Effective Teaching Outcomes in Nigeria. Open Access Library Journal, 2: e1689.

http://dx.doi.org/10.4236/oalib.1101689 
video games. Audio books are now increasing their share in the market of educational materials, and the habit of reading traditional books is threatened and could indeed be on the decline. The new technologies are therefore negatively impacting the book industry and the book industry must come up with some bold strategic responses to stem this tide of attrition of its clients or face progressive extinction. Books are necessary for education. But for books to survive this onslaught from the new technologies, it must find new ways to redesign and re-engineer itself, to increase its appeal to readers and to regain some of its lost markets. This paper believes that the solution to the challenge of survival could lie in good quality, value adding content, interactive and well illustrated books. Specifically, the writers will argue the role that good illustrations can play in this much needed task of saving the book so that it will continue to play its irreplaceable role in propagation of literacy and in the education of the citizens of any nation and the world.

The process of education is essentially one of communications. Such a communication involves the transmission of knowledge, attitudes, beliefs and attitudes from a teacher to a learner. As facilitator in this transmission, a good teacher should be an effective communicator. The learner must also be an effective listener. To become educated is to evolve a relationship with that which has been achieved by man in man's history, and direct oneself with its use towards the possibilities of the future. In a learning situation, learners are subjected to the influences of teachers through the learning materials generated by authors, publishers and other creative people in the production of books and other visual instructional media [1]. In this process of learning and communication, learners and teachers are engaged in a constant stream of exchanges which are often mediated by and facilitated by instructional materials. These exchanges involve the activation of cognitive processes by the learner with the active support and stimulation by the teacher, and the end result of which is the further development of skills, effects and competencies by the same learner. The teacher and the learner share equal responsibility for effective communication. The communication loop is complete when the learner understands, feels or behaves and responds positively to the message of the teacher. If this does not occur, the communication and learning process has not taken place.

There are many factors that contribute to the effectiveness of teaching and learning situation. These factors include the knowledge and communication skills of the teacher, the environment, the learner himself/herself, his/her readiness and his/her field of experience, the types of books and other forms of instructional materials exposed to him/her. It has been argued by scholars [2]-[5] that instructional materials play a very important role in all learning situations. Indeed giving their importance, scholars [2] [4] [5] have argued that the greatest care must be deployed in their conceptualization, design and development. It is partly a reflection of the pedagogic utility of instructional materials that a theory of their design and use has now been developed. This emerging theory of instructional materials recognises the multifaceted nature of learning and instructional materials and now argues that instructional materials design is the meeting point of disciplines as diverse as art, semiotics, economics, culture, psychology, sociology, design and technology [2]-[5]. Books are one of the oldest and most used instructional materials; despite the challenges of the digital age, the book remains one of the most reliable repositories and transmitters of cultural knowledge, effects and skills, and its production calls for the activation of great technical skills, practical and pedagogic insights and trade-offs. The finished book we thus see on shelves in the bookshop or in the hands of learners is the result of interactions between a number of disciplines and persons with expertise in diverse fields. As textbooks are the major focus of this paper, the next section examines textbook in greater detail.

\section{Textbook Publishing as Information, Education and Communication Material}

Information, Education and Communication (IEC) materials as instructional media come in different forms: Journals, Newspapers, Books, etc. Textbook publishing remains a very important IEC medium. The term "publishing” means, in the broadest sense, making something publicly known. Usually, it refers to the issuing of printed materials such as textbooks, periodicals, and the like [6]. The importance of reliable development and production of well-illustrated textbooks as instructional media can neither be underestimated nor ignored if a nation is to make progress in the educational sector. Good and well-illustrated books are a requirement for good book development and provision. The role of good books in the teaching and learning process today is very important. It is a vital force in modern education, the use of internet notwithstanding, it offers a tremendous opportunity for developing early child education in countries like Nigeria [7]. A well-illustrated book is a purveyor of ideas. It is certainly one of man's major creations. Books provide information and knowledge and develop the 
imagination to produce a cultured and educated person. It has been and will remain one of the greatest civilizing influences available to man [8] [9].

\section{The Importance of Illustrative Materials}

Illustrative materials are important to all levels of learning, as they have positive influences on teaching and learning. It is important to note that well illustrated textbooks are indispensable to effective teaching and learning. The textbook market today in virtually every subject area is awash with such a wide variety of textbooks in that the choice of one textbook over the other is becoming increasingly difficult. Book publishers are making efforts to publish and provide more books into the market to supplement, or displace the existing ones. This is because well-illustrated textbooks have been recognized to lend credit to teaching and learning. Books are crucial in the entire learning processes: beginning with the pre-primary school to the creative or scientific masterpiece of different fields at the tertiary education. Books in right numbers and in various disciplines constitute almost the pre-condition in a civilized society, where readers and books are brought together [8].

Clarence Day as cited in Folarin [10], writing on the uniqueness and importance of textbooks in the development of the human race, comments thus:

The world of books is the most remarkable creation of man. Nothing else that he builds ever lasts... But in the world of books, are volumes that have seen things happen again and again and yet lives on, still young, still as fresh as the day they were written, still telling man's heart of the hearts of men centuries dead.

The role of book in literacy development is immeasurable. No wonder, the level of development in a nation can be directly linked to its level of literacy which book fosters. Therefore, a developed nation is a book conscious nation.

This assertion is particularly apt as it summarises the role that a culture of reading, literacy and textbooks can play in the educational and socio-economic development of Nigeria, a developing country that actively pursues development through strategic and sizeable investments in the growth of human capital and its human resources. It is no accident that societies with the highest reading cultures and advanced levels of literacy are the most performing in nearly every indicator of human development [11]. Thus the view [8] that the book is a dynamic product and monumental property of every civilized society is one that resonates with the position argued in this paper. With specific regard to the educational industry, the argument [8] that the book is a rich source of information to the teachers and students, a gold mine of knowledge for researchers and scholars, and a fountain of pleasure and leisure to general readers is thus one that conveys an eternal verity. But for books to play this vital role to its fullest, their design and production must reflect some very essential considerations and inputs. These are examined in the next section of this paper.

\section{Use of Illustrative Materials for Effective Communication}

Many factors contribute to the effectiveness of any textbook as a medium of communication. Illustrations play significant roles in the effectiveness of any textbook as an information, communication and education [IEC] material. Good illustrations add value to a textbook while bad illustrations destroy and distort the flow of communication between the author and the reader. Textbooks play a central role in the teaching and learning of any subject. The effectiveness of any learning/instructional situation depends in part, on the quality of the textbooks that are available to aid instruction. The quality of textbooks is enhanced by the quality of the illustrative materials used in the origination and pre-press graphics. This means that the publisher, the editors and graphic designers must understand illustrative forms and use them creatively. Only effective and relevant illustrations should be used in the teaching and learning interactions [12] [13].

A good knowledge of the quality of illustration in textbooks could add to the teacher's knowledge of important criteria to use in evaluating illustrations before selecting appropriate books. Authors and publishers need to be aware of the role types of illustration play in making textbooks teacher-learner friendly. Policy planners, curriculum experts in various subject areas and instructional specialists may thus need to come together to design and to spell out the illustrative qualities that are expected in textbooks. This suggested collaboration of experts aids the final production of textbooks that are that respond the imperatives of curricular and pedagogic adequacy, cultural suitability, social acceptability and economic affordability. Two illustrations may suffice to drive home the points being raised here. In the course of adapting textbooks for use by readers in Somaliland, a meeting of experts from different fields discovered that the use of a monkey as a mascot was unacceptable to persons from 
Somaliland. A new mascot in the form of a camel had to be adopted. This is an example of illustrations in books benefiting from multi-disciplinary inputs and swaying to the demands of cultural suitability. In another instance, a team of experts made up science educators, gender experts, curriculum specialists and textbook illustrators found out that the typical illustration of the scientist in science textbooks as a male in white overalls was sending unintended messages to female students and discouraging these from pursuing careers in the sciences. New illustrations with balanced roles and appearances for males and females in science and technology were then produced, and this singular decision and act saved the books from charges of sexism on the one hand and also enabled them to now become sources of encouragement to female pupils grappling with science learning. Once again, multi-disciplinary collaboration in this example was shown as invaluable in contributing to the improvement of illustrations in text books. Indeed the value of such multi-disciplinary dialogue and collaboration lies ultimately in helping determine the appropriacy and adequacy of certain illustrative types, whether some illustrative types are culturally suitable, whether they respond the tents of clarity, unambiguity, perceptual salience and whether or not there is a need to increase or decrease the use of a particular illustrative type for a particular class of learners, among other benefits. The next section examines illustrations and illustrative materials in some depth.

\section{Sources of Illustrative Materials}

Illustrators are communicators. They translate written and oral information into visual information for a target heterogeneous audience. Illustrations are done with the skill and ingenuity of a story teller who clearly explains the present, the past as well as the future; and before the coming of photography, true stories were also visually explained by illustrations. Communication, which is message and medium, has been explained as the process by which individuals, such as teachers share information, ideas and attitudes [10] [14]. It involves the sorting, selecting and sharing of symbols, in such a way as to help the receiver elicit from his/her own mind a meaning similar to that contained in the mind of the author, who is the message source. When book illustrators select symbols for their messages, they should keep in mind that each reader has a different frame of reference and that as a result, certain symbols may mean different things to different readers. A frame of reference (sometimes called field of experience) is a set of individual experiences each person possesses; no two readers have exactly the same experience [14]. This is collaborated by Marshal Mcluhan's principle of selective perception which states:

Everyone has his own set of goggles and we all think that what we see with our set of goggles is what everyone sees [10].

\section{Illustration Types and Their Uses for Book Publishing}

Illustrations are artistic or visual representation through any type of drawing painting, or photograph. It is a two dimensional art. Illustrations are as important vehicle of communication as the printed words in a book. Illustrations increase the effectiveness of textbooks as instructional and learning media. Here we define textbook effectiveness as the degree to which and the ease with textbook facilitate learning and lead to desired learning outcomes. Textbook effectiveness results from the interaction of a number of elements. One set of elements is the content, relevance of content, sequence of content and pedagogic progression of content. Another set of determining elements are age appropriacy in the choice of examples, accuracy of contents, gender and socio-cultural sensitivity as well as inclusiveness of the themes treated and on the quality, quantity and relevance of illustrations in it. Illustrations are thus major contributors in textbook effectiveness. Aesthetically, good illustrations make books more captivating. Textbooks can be marred by poor illustrations and it is therefore important that great care is given in their design and production. Illustration types for book production include: Free-hand-illustration which means pictures drawn by hand; photographs which are made through snap shots using cameras; colour illustrations and paintings which involve the use of brush and colour as opposed to that which is executed in black and white; and illustration in line or wash.

Of all the problems that confront the lovers of art, one of the most important is that of discerning and determining real quality. Evaluating an illustration could be a subjective exercise which demands adequate guidance. We shall return to this in the last section that looks at relevant evaluative criteria for textbook illustrations. Meanwhile, let us simply observe that book illustrators, publishers, art educators, and creative art scholars agree that the study of the elements in a work of art is the necessary basis for textbook illustration and picture evalua- 
tion. Evaluations based mainly on beauty often drive most teachers and learners to regard realistic drawings as the best illustrative style. While such a perception may be correct for Pre-primary and Primary school books, it may not necessarily be the case for learners at higher levels given their superior cognitive make ups. Indeed, this paper is of the opinion that although book illustrator's visual conceptions are based on the memory of the real appearance of the natural objects, realism is not all that could be said about a picture. The most accurate representation in art is not necessarily the best work of art. An erudite and experienced evaluator must consider other elements of a picture when assessing an illustration apart from realism. An illustration for a textbook must be made in the shape, design or pattern, harmony of mass and colour. An illustration should also be judged in the light of its intention because pictures do not have the same purpose. A picture which is meant for a textbook has a different intention from that meant for "art-for-art-sake" or decoration alone. It is important to mention that the ability of the evaluator to empathize with the illustrator could lend success to a good evaluation of a picture. Each artist is a distinct individual whose pictures will always exhibit his particular set of assumptions, sensibilities and mannerisms. The reader is also a distinct individual, such that he/she will respond only to those qualities that are meaningful to him/her.

\section{Suggestions for Coring Standards for Effective Illustration Evaluation}

Given the importance of illustration for textbook effectiveness as argued in this paper, it becomes very important that valid, objective and universally acceptable criteria are developed and agreed upon to guide the evaluation of illustration in textbooks. Evaluation can be broadly defined as that that activity which measures and determines the worthwhile of an activity or a product. A search of the numerous scholarly contributions in the area of evaluation of textbook illustrations [15]-[17] yields the following criteria which are very useful in evaluating the effectiveness or otherwise of illustrations for textbook publishing.

1) Proportion which is the inter-relationship of parts in an illustration.

2) Balance which has to do with stability. It is the effect of one element to the other in an illustration either of dominance or of recession.

3) Variety/regularity is used to refer to how different and illustration is from another.

4) Rhythm is used to refer to change or repeated patterns in an illustration.

5) Harmony in the artistic common-place which means agreement of parts.

6) Placement is the placing of an illustration either near or far from its content material.

7) Quality is the additive value derived from the scores on relevance, tone, size, clarity, balance, variety/ regularity, rhythm, harmony and placement.

8) Relevance is the suitability of the illustration within the context of the content material.

9) Tone is the shade of the illustration, i.e. how bright or dull an illustration is.

10) Size refers to how big or small an illustration is.

11) Clarity refers to how legible and comprehensible an illustration is.

The publisher and the textbook evaluator must have in mind at all times that in any page layout, apart from the chapter heading, the illustration is the most effective way of getting a reader's attention. Good illustrations in book publishing should do one or more of the following:

1) Capture the attention of the reader.

2) Identify the subject of the message.

3) Arouse interest of the reader in reading the headline/chapter heading.

4) Help convince the reader of the truth of claims made in the text.

A good textbook offers scope for three distinct groups of graphics: Good typography, page layout to make the author's message reader friendly; secondly, good illustrations to interpret and reinforce the key messages in the accompanying text it invisual forms; and thirdly, graceful cover to attract the eye of the potential consumer.

\section{Conclusions}

This paper affirms that the success of textbook evaluation which is very crucial in the educational progress is dependent on many factors. These include the types of illustrative materials used in the text books originated and designed for effective teaching and learning. This work also noted that illustrative materials in textbooks are imperative to all levels of learning because they have positive influences on teaching and learning. Life-transforming ideas have always come to learners through books, especially well-illustrated books. 
These standards-proportion, balance, variety, rhythm, harmony, placement, relevance and suitability of illustration within the context of the content materials aid evaluation. All these works together make textbooks reader-friendly. The importance of these standards in evaluating the effectiveness or otherwise of illustrations for textbooks has been discussed.

Investments in book publishing and in other instructional materials are investments for the country's future. Government and policy planners should give the utmost attention to textbook publishing and evaluation. In our current age, giving the threats posed to book reading by new and emergent technologies, this call assumes the greatest urgency.

\section{References}

[1] Okwilagwe, O.A. (2001) Book Publishing in Nigeria, Ibadan. Stirling-Horder Publishers Nigeria Limited, Ibadan.

[2] Romiszowski, A.J. (1981) Designing Instructional Systems. Kogan Page Ltd., London.

[3] Ihebuzor, N.A. (1996) Guidelines for the Production of Integrated Instructional Materials for EPD. UNESCO-BREDA, Dakar.

[4] Ihebuzor, N.A. (1991) The Design of Language Textbooks Evaluation Schemes. Institute Journal of Studies in Education, 2, 121-126.

[5] Ihebuzor, N.A. (1995) Issues in Language Book Design. Journal of Book Research \& Development, 1, 59-67.

[6] Madu, E. (2002) The Basics for Audio-Visual Librarianship. Evi-Coleman Publication, Ibadan.

[7] Aigbokhai, S. (1984) Target 6-Paper. Report on the First Nigerian National Congress on Books, Lagos, 21-25 March 1983.

[8] Ubahakwe, A. (1984) Creating a Reading Public. Report of the First Nigerian National Congress on Books, Lagos, 21-25 March 1983.

[9] Achebe, N. (2008) Books and Life Long Education. The Publisher Magazine, Magazine of the Nigerian Publishers' Association, 15, 3-4.

[10] Folarin, B. (1998) Theories of Mass Communication: An Introductory Text. Stirling Horden Publishers (Nigeria) Ltd., Ibadan.

[11] UNESCO (2015) Global Monitoring Report on EFA. UNESCO, Paris.

[12] Oso, L., Osunbiyi, B. and Biobaku, L., Eds. (2008) Book Publishing: A Practical Guide. African Resource Communication, Lagos.

[13] Kalejaiye, O. and Akangbe, C. (2007) Book Publishing and Its Challenges: The Nigerian Experience. International Journal of Communication, 7, 71-72.

[14] Wilson, S. (1997) Mass Media, Mass Culture. An Introduction. McGraw-Hill, New York.

[15] Ihebuzor, L. (2006) The Art of Book Publishing: From Conception to Consumption. College Press and Publishers Ltd., Ibadan.

[16] Tarbiat, E.Y. and Ferdowsi, S.S. (2014) Design and Application of a "Textbook Visual Effects” Evaluation Checklist. Theory and Practice in Language Studies, 4, 473-480. http://dx.doi.org/10.4304/tpls.4.3.473-480

[17] Prince Edward Island, Department of Education (2008) Evaluation and Selection of Learning Resources: A Guide. Prince Edward Island, Department of Education Charlottetown, Prince Edward Island, Canada. 